\title{
Bazı Mısır (Zea mays L.) Çeşitlerinde Verim ve Kalite Özelliklerinin Belirlenmesi
}

\author{
Sevda KILINÇ ${ }^{1}$ (D), Çetin KARADEMİR ${ }^{2}$ (iD), Zehra EKIN ${ }^{3}$ (D) \\ ${ }^{1}$ GAP Uluslararası Tarımsal Araştırma ve Eğitim Merkezi Müdürlüğü, Diyarbakır, ${ }^{2}$ Siirt Üniversitesi Ziraat Fakültesi Tarla Bitkileri \\ Bölümü, Siirt, ${ }^{3}$ Van Yüzüncü Yıl Üniversitesi Ziraat Fakültesi Tarla Bitkileri Bölümü, Van \\ 凶: cetinkarademir@siirt.edu.tr
}

\section{ÖZET}

$\mathrm{Bu}$ çalışma, farklı özelliklere sahip tane mısır çeşitlerinde kalite, verim ve verim unsurlarının belirlenmesi ve bölgeye uygun tane misır çeşidinin önerilmesi amacıyla 2015 yılında Diyarbakır GAP Uluslar Arası Tarımsal Araştırma ve Eğitim merkezi Müdürlüğü deneme alanında, tesadüf blokları deneme desenine göre 4 tekerrürlü olarak yürütülmüştür. Çalışmada materyal olarak 6 misır çeşidi (PR31D24, Kalipso, 70MAY82, Suerto, P1921, DKC6724) kullanılmıştır. Elde edilen sonuçlara göre çeşitler arasında, koçan uzunluğu, koçan kalınlığı, sap kalınlığı, bitkide koçan sayısı, tane/koçan oranı, 1000 tane ağırlığı, tane nemi, nişasta oranı, ham yağ oranı, hektolitre ağırlığı özellikleri yönünden istatistiki farkların önemli olduğu belirlenmiştir. En yüksek tane verimi $1518.10 \mathrm{~kg} \mathrm{da}^{-1}$ ile P1921 çeşidinden elde edilmiştir.

DOI:10.18016/ksutarimdoga.vi.463813

Makale Tarihçesi

Geliş Tarihi : 20.02.2018

Kabul Tarihi : 19.04.2018

Anahtar Kelimeler

Misir,

verim,

kalite, adaptasyon

\section{Araştırma Makalesi}

\section{Determination of Yield and Quality Characteristics in Some Maize (Zea mays L.) Varieties}

\section{ABSTRACT}

This study was carried out to determine quality, yield and yield components and suggesting suitable maize varieties for the region. The research was laid out as randomized complete block design with four replications in 2015 maize growing season in Diyarbakır GAP International Agricultural Research and Training Center. PR31D24, Kalipso, 70MAY82, Suerto, P1921, DKC6724 grain maize varieties with different properties were used as material. According to the obtained results, there were significant differences among varieties in terms of ear length, ear diameter, stem diameter, the number of ear per plant, kernel/ear rate, 1000 kernel weight, grain moisture at harvesting, starch rate, crude fat rate and hectoliter. The P1921 variety sustained the highest yield of $1518.10 \mathrm{~kg} \mathrm{da}^{-1}$.

\section{Article History}

Received : 20.02.2018

Accepted : 19.04.2018

\section{Keywords \\ Adaptation, maize, quality, yield}

\section{Research Article}

To cite: Kılınç S, Karademir Ç, Ekin Z Ö 2018. Bazı Mısır (Zea mays L.) Çeşitlerinde Verim ve Kalite Özelliklerinin Belirlenmesi. KSÜ Tar Doğa Derg 21(6) : 809-816, DOI:10.18016/ksutarimdoga.vi.463813

\section{GİISŞ}

Misır insan gidası ve hayvan yemi olarak kullanılmasının yanı sıra, sanayide de alkol, ispirto, yağ, irmik vs. gibi ürünlerin üretiminde hammadde olarak kullanılmaktadır. Dünya tahıl üretiminde mısır, 183 milyon hektar ekim alanı ile buğdaydan sonra ikinci, 1.021 milyon ton üretim ve ortalama 502 $\mathrm{kg} / \mathrm{da}$ verimle birinci sirada yer almaktadır(Anonim, 2016a).

Ülkemizde mısır üretim açığının bulunması, mısır kullanım alanlarının genişliği, mısıra dayalı sanayinin gelişen bir sanayi olması ve bu sanayi ürünlerinin diğer sektörler için ara hammadde olması, Türkiye'nin coğrafi konumu nedeniyle misır ve misıra dayalı ürünlerde ihracat potansiyelinin bulunması, misıra dayalı sanayi sektörünün büyük oranda yabancı sermayeye bağımlı olması ve Türkiye'ye yabancı sermaye akışını sağlayacak sektörlerden birisi olması gibi temel nedenlerle, ülkemiz açısından mısır tarımının önemi her geçen gün artmaktadır. (Vartanlı ve Emeklier, 2007).

Türkiye'de tarımsal sanayinin ihtiyacını karşılamak için mısırın yeterli miktarda ve uygun kalitede üretilmesi gerekmektedir.

Mısır üretimini artırmak için yapılması gereken çalışmaların başında bölgenin ekolojik koşullarına uygun, çevresel faktörlere dayanıklı çeşitlerin seçimi, kaliteli tohumluk kullanımı ve üretimde melez çeşitlerin yaygınlaştırılması gelmektedir.

Ülkemiz 2015 yılı tane mısır ekim alanı 6.881.699 da, üretimimiz 6.400.000 ton ve verim ortalaması ise 933 $\mathrm{kg}$ da $^{-1}$ 'dır. Güneydoğu Anadolu Bölgesinde ise tane mısır ekim alanı 2.027.000 da, üretim 1.916.125 ton ve verim ortalaması ise $952 \mathrm{~kg} \mathrm{da}^{-1}$ 'dır. Ülkemizdeki 
üretimin \%31'i bu bölgeden karşılanmaktadır (Anonim, 2016b).

Ülkemizde mısır üretimin alan dağılımında yıllara göre hızlı değişimler yaşanmaktadır. 2015 yılı verilerine göre, misır ekiliş alanı yönünden Güneydoğu Anadolu bölgesi birinci sırada yer almıştır. Güneydoğu Anadolu bölgesi misırın ekim alanı yönünden en hızlı artış gösterdiği bölgedir. Bölgede pamuğa alternatif mısır ekilişinin artması, ikinci ürün mısır üretiminin bölgede gelişmesi ve yüksek sıcaklığa dayanıklı, dik yapraklı çeşitlerin geliştirilmesi üretimi önemli derecede arttırmıştır.

$\mathrm{Bu}$ araştırma, farklı özelliklere sahip bazı tane mısır çeşitlerinde kalite, verim ve verim unsurlarının belirlenmesi, bölgeye uygun tane mısır çeşitlerinin önerilmesi amacıyla yürütülmüştür.

\section{MATERYAL ve METOT}

Deneme GAP Uluslararası Tarımsal Araştırma ve Eğitim Merkezi Müdürlüğü(GAP UTAEM) deneme alanında 2015 yılında yürütülmüştür. Deneme yeri, Dicle nehri kenarında taban arazide olup, denizden yüksekliği 500-700 metre civarındadır. Denemenin yürütüldüğü GAP Uluslararası Tarımsal Araştırma ve Eğitim Merkezi Müdürlüğü deneme alanının toprakları, kırmızı-kahverengi olup, yörede büyük toprak grubunun hakim olduğu Siirt-DiyarbakırŞanlıurfa yayı üzerinde bulunmaktadır. Bu topraklar düz ya da düze yakın eğimlerde derin veya orta derin ABC profilli horizontal topraklar olup, bunların organik madde ve fosfor kapsamları düşük, potasyum ve kalsiyum kapsamları ise yüksektir. Bu alanların tuzluluk ve alkalilik problemleri yoktur. Toprak profilleri boyunca $(0-150 \mathrm{~cm})$ içerdikleri yüksek oranda kil (\% 49-67) nedeniyle kışları genişleyip şişmekte, yazları ise büzülerek derin çatlaklar oluşturmaktadır (Anonim, 2011).

2015 yılı deneme alanından alınan 0-30 cm derinlikten alınan toprak örneklerinin GAP Uluslararası Tarımsal Araştırma ve Eğitim Merkezi Laboratuvarında yapılan analiz sonuçları Çizelge 1'de verilmiştir. Deneme alanının toprak özellikleri; killi ve orta alkali olup organik maddesi düşüktür.

Araştırmanın yürütüldüğü Diyarbakır ilinde, yazları sıcak, kurak ve uzun, kışları soğuk ve az yağışlı bir iklim görülmektedir. Yıllık ortalama yağış miktarı 496 milimetredir. (Anonim, 2015). Çizelge 2 incelendiğinde denemenin yürütüldüğü 2015 yllı ve uzun yıllar ortalama ve maksimum sıcaklık değerlerinin Temmuz ayında gerçekleştiği izlenebilmektedir. Ayrıca araştırmanın yürütüldüğü 2015 yılı Temmuz, Ağustos ve Eylül aylarındaki maksimum sıcaklıklar uzun yıllar maksimum sicaklıklardan daha yüksek olarak gerçekleşmiştir.

Çalışmada bölge iklim koşullarına uyum gösterebilen ve pazar değeri yüksek 6 çeşit materyal olarak kullanılmıştır (Çizelge 3).

Tesadüf Blokları Deneme Desenine göre dört tekerrürlü olarak yürütülen denemede ekim, 27 Nisan 2015 tarihinde $2.8 \times 5 \mathrm{~m}=14.0 \mathrm{~m}^{2}$ boyutundaki parsellere, her parselde 4 sira olacak şekilde $70 \mathrm{~cm}$ sira arası ve $20 \mathrm{~cm}$ sıra üzeri mesafesi dikkate alınarak yapılmıştır.

Çizelge 1. Deneme alanına ait toprak analiz sonucu

\begin{tabular}{|c|c|c|c|c|c|c|}
\hline $\begin{array}{c}\text { Bünye } \\
\text { Sinifi }\end{array}$ & $\begin{array}{c}\text { Toplam } \\
\text { Tuz (\%) }\end{array}$ & $\mathrm{Ph}$ & Kireç $\mathrm{CaCO}_{3}(\%)$ & $\begin{array}{c}\text { Fosfor } \mathrm{P}_{2} \mathrm{O}_{5} \\
\left(\mathrm{~kg} \mathrm{da}^{-1}\right)\end{array}$ & $\begin{array}{c}\text { Organik Madde } \\
(\%)\end{array}$ & $\begin{array}{c}\text { Su ile Doygunluk } \\
(\%)\end{array}$ \\
\hline Killi & 0.071 & 7.92 & 12.36 & 0.56 & 0.85 & 74 \\
\hline
\end{tabular}

Çizelge 2.Diyarbakır İlinin 2015 Yılı ve uzun yıllara ait iklim verileri

\begin{tabular}{|c|c|c|c|c|c|c|c|c|}
\hline & \multicolumn{2}{|c|}{ Ortalama Sicaklık $\left({ }^{\circ} \mathrm{C}\right)$} & \multicolumn{2}{|c|}{ Maksimum sicaklık $\left({ }^{0} \mathrm{C}\right)$} & \multicolumn{2}{|c|}{ Yağ1ş (mm) } & \multicolumn{2}{|c|}{ Ortalama Nispi Nem (\%) } \\
\hline Aylar & 2015 & $\begin{array}{l}\text { Uzun } \\
\text { Yillar }\end{array}$ & 2015 & $\begin{array}{l}\text { Uzun } \\
\text { Yillar }\end{array}$ & 2015 & $\begin{array}{l}\text { Uzun } \\
\text { Yillar }\end{array}$ & 2015 & $\begin{array}{l}\text { Uzun } \\
\text { Yillar }\end{array}$ \\
\hline Nisan & 12.4 & 13.8 & 19.2 & 20.4 & 48.6 & 68.7 & 69.6 & 56.0 \\
\hline Mayıs & 18.8 & 19.2 & 27.1 & 26.5 & 48.2 & 44.3 & 57.6 & 31.0 \\
\hline Haziran & 26.1 & 26.3 & 34.4 & 33.6 & 7.4 & 8.8 & 34.5 & 27.0 \\
\hline Temmuz & 31.7 & 31.1 & 40.0 & 38.4 & 0.0 & 0.5 & 21.8 & 28.0 \\
\hline Ağustos & 30.9 & 30.4 & 39.3 & 38.2 & 0.0 & 0.4 & 25.5 & 32.0 \\
\hline Eylül & 27.4 & 24.8 & 36.2 & 33.3 & 0.0 & 4.3 & 25.7 & 48.0 \\
\hline Ekim & 18.4 & 17.3 & 25.1 & 25.3 & 84.2 & 32.3 & 58.1 & 56.0 \\
\hline Toplam & 165.7 & 162.9 & 221.3 & 215.7 & 188.4 & 159.3 & 292.8 & 278 \\
\hline Ortalama & 23.67 & 23.27 & 31.61 & 30.81 & 26.91 & 22.75 & 41.82 & 39.71 \\
\hline
\end{tabular}


Çizelge 3. Denemede kullanılan mısır çeşitleri ve temin edilen kuruluşlar.

\begin{tabular}{lll}
\hline Çeşit adı & Olum grubu & Ceşit sahibi kuruluşlar \\
\hline PR31D24 & FAO 650-670 & Pioneer Tohumculuk A.Ş. \\
P1921 & FAO 700 & Pioneer Tohumculuk A.Ş. \\
KALIPSO & FAO 650-700 & KWS Türk Tarım Tic.A.Ş. \\
70MAY82 & FAO 700 & May Agro Tohumculuk San. ve Tic. A.Ş. \\
SUERTO & FAO 700 & Polen Tohumculuk Ltd. Şti \\
DKC6724 & FAO 700 & Monsanto Gıda ve Tarım Tic.Ltd.Şti. \\
\hline
\end{tabular}

Denemede ekim öncesi deneme alanından alınan toprak örneğinin analiz sonuçlarına göre dekara $20 \mathrm{~kg}$ saf azot $(\mathrm{N}), 10 \mathrm{~kg}$ saf fosfor $\left(\mathrm{P}_{2} \mathrm{O}_{5}\right)$ verilmiştir. Ekim ile birlikte $10 \mathrm{~kg}^{-1} \mathrm{da}^{-1} \mathrm{~N}$ ve $10 \mathrm{~kg}^{\mathrm{da}} \mathrm{d}^{-1} \mathrm{P}_{2} \mathrm{O}_{5}$ 20-20-0 kompoze gübre formunda, geri kalan $\mathrm{N}$ ise bitkiler $40^{-}$ $50 \mathrm{~cm}$ boylandığında \% 33'lük Amonyum Nitrat olarak verilmiştir. Bitkiler 10-15 cm boya ulaştığında elle çapalama ve tekleme, bitkiler $40-50 \mathrm{~cm}$ boylanınca traktörle ikinci çapa, boğaz doldurma ve azotlu gübreleme işlemleri yapılmıştır. Sulamalar; ekimden sonra ilk sulama yağmurlama, sonraki dönemde ise karık sulama yöntemi şeklinde 9 sulama yapılmıştır. 29.09.2015 tarihinde toplam parsel alanı $7 \mathrm{~m}^{2}$ olacak şekilde ortadaki iki sıra hasat edilmiştir. Araştırmadan elde edilen verilere varyans analizi uygulanarak, önemli görülen özellikler LSD testine tabi tutulmuştur.
Araştırmada incelenen özelliklerin ölçüm ve gözlemleri Gıda Tarım ve Hayvancılık Bakanlığı, Tarımsal Değerleri Ölçme Denemeleri Teknik Talimatı (2010) dikkate alınarak yapılmıştır. Araştırmada tepe püskülü çıkarma süresi, koçan püskülü çıkarma süresi, bitki boyu, ilk koçan yüksekliği, sap kalınlığı, koçan uzunluğu, koçan kalınlığı, bitkide koçan sayısı, tane/koçan oranı, 1000 tane ağırlığı, birim alan tane verimi, hasatta tane nemi, ham protein, ham yağ, hektolitre ağırlığı, nişasta oranı gözlemleri alınmıştır.

\section{BULGULAR ve TARTIŞMA}

Yapılan araştırmada; tepe püskülü çıkarma süresi, koçan püskülü çıkarma süresi, bitki boyu, ilk koçan yüksekliği, sap kalınlığı, koçan uzunluğu, koçan kalınlığına ait ortalama değerler ve $\operatorname{LSD}(0.05)$ testine göre oluşan gruplar Çizelge 4'te verilmiştir.

Çizelge 4. Tepe püskülü çıkarma süresi, koçan püskülü çıkarma süresi, bitki boyu, ilk koçan yüksekliği, sap kalınlığı, koçan uzunluğu, kaçan kalınlığı ortalama değerleri

\begin{tabular}{|c|c|c|c|c|c|c|c|}
\hline Çeşit & $\begin{array}{l}\text { Tepe Püskülü } \\
\text { Çıkarma } \\
\text { Süresi (gün) }\end{array}$ & $\begin{array}{l}\text { Koçan Püskülü } \\
\text { Çıkarma } \\
\text { Süresi (gün) }\end{array}$ & $\begin{array}{l}\text { Bitki Boyu } \\
(\mathrm{cm})\end{array}$ & $\begin{array}{l}\text { İlk Koçan } \\
\text { Yüksekliği } \\
(\mathrm{cm})\end{array}$ & $\begin{array}{c}\text { Sap } \\
\text { Kalınlı̆ğ } \\
(\mathrm{mm})\end{array}$ & $\begin{array}{c}\text { Koçan } \\
\text { Uzunluğu } \\
\text { (cm) }\end{array}$ & $\begin{array}{c}\text { Koçan } \\
\text { Kalınlığg } \\
(\mathrm{mm})\end{array}$ \\
\hline PR31D24 & 68.50 & 72.50 & 273.5 & 100.5 & $21.8 \mathrm{ab}$ & $20.7 \mathrm{bc}$ & $46.0 \mathrm{bc}$ \\
\hline SUERTO & 66.25 & 73.50 & 259.5 & 104.7 & $22.4 \mathrm{ab}$ & $20.0 \mathrm{c}$ & $46.6 \mathrm{~b}$ \\
\hline 70MAY82 & 67.50 & 72.25 & 272.2 & 100.6 & $22.7 \mathrm{a}$ & $22.0 \mathrm{a}$ & $44.5 \mathrm{c}$ \\
\hline KALİPSO & 68.00 & 71.75 & 282.3 & 102.6 & $23.5 \mathrm{a}$ & $21.5 \mathrm{ab}$ & $45.7 \mathrm{bc}$ \\
\hline P1921 & 68.50 & 70.50 & 271.5 & 88.0 & $20.5 \mathrm{~b}$ & $21.2 \mathrm{ab}$ & $47.1 \mathrm{~b}$ \\
\hline DKC6724 & 65.25 & 70.50 & 251.8 & 93.5 & $20.7 \mathrm{~b}$ & $19.5 \mathrm{c}$ & $49.0 \mathrm{a}$ \\
\hline ORTALAMA & 67.33 & 71.83 & 268.5 & 98.3 & 21.9 & 20.8 & 46.5 \\
\hline $\operatorname{LSD}_{(0,05)}$ & Ö.D & Ö.D & Ö.D & Ö.D & $1.92^{*}$ & $1.18^{* *}$ & $1.79^{* *}$ \\
\hline $\mathrm{CV}(\%)$ & 2.53 & 3.29 & 7.42 & 8.12 & 5.81 & 3.78 & 2.55 \\
\hline
\end{tabular}

* Aynı harfle gösterilen ortalamalar arasındaki farklar 0.05 düzeyinde önemli değildir.

**Aynı harfle gösterilen ortalamalar arasındaki farklar 0,01 düzeyinde önemli değildir

Tepe Püskülü Çıkarma Süresi (gün): Tepe püskülü ile koçan püskülü çıkarma süresi arasındaki geçen süre ortalama 2.00 - 7.25 gün arasında değişmiştir (Çizelge 4). Bu süre -tozlanma-döllenme ve verimi etkileyen önemli bir özelliktir. Tepe püskülü ile koçan püskülü arasındaki geçen süre bakımından en kısa süreye sahip çeşit P1921, en uzun süreye sahip çeşidin ise SUERTO çeşidi olduğu tespit edilmiştir. Çizelge 4 incelendiğinde tepe püskülü çıkarma süresi (gün) bakımından çeşitler arasında önemli farklılıkların bulunmadiğı izlenebilmektedir. Çizelge 4'ten tepe püskülü çıkarma süresi özelliğine ilişskin, çeşitlere ait ortalama değerlerin, 65.25 ile 68.50 gün arasında değiştiği; çeşitler arasında tepe püskülü çıkarma yönünden önemli bir istatistiki fark olmamasına rağmen PR31D24 çeşidi ile P1921 çeşitlerinin en yüksek değeri (68.50) gösterdiği, DKC6724 çeşidinin ise en düşük tepe püskülü çıkarma süresi değerini (65.25) oluşturduğu saptanmıştır. Bulgularımız; Cesurer (1994), Babaoğlu (2003), Vartanlı (2005), Özsisli (2010), Atakul ve ark. (2014), Erdal (2014), Kahraman ve ark. (2014), Kılınç ve ark. (2014), Kahraman (2016)'nın bulguları ile benzerlik göstermiştir. Çalışmada elde edilen bulgular Sarikurt (2005)'un bulgularından daha düşük, İdikut ve Kara 
(2013)'nın bulgularından daha yüksek değerler göstermiştir.

Koçan Püskülü Çıkarma Süresi (gün): Çizelge 4 incelendiğinde koçan püskülü çıkarma süresi (gün) bakımından çeşitler arasında önemli farklılıkların bulunmadığı izlenebilmektedir. Çizelge 4'ten koçan püskülü çıkarma süresi özelliğine ilişkin, çeşitlere ait ortalama değerlerin, 70.50 ile 73.50 gün arasında değiştiği; SUERTO çeşidinin en yüksek tepe püskülü çıkarma süresi değerini (73.50), DKC6724 ile P1921 çeşitlerinin ise en düşük koçan püskülü çıkarma süresi değerini (70.50) oluşturduğu saptanmıştır. Bulgularımız; Babaoğlu (2003), Kahraman (2016)'nın bulguları ile paralellik gösterirken, İdikut ve Kara (2013)'nın bulgularından daha yüksek değerler elde edilmiştir.

Bitki Boyu (cm): Çizelge 4'ten bitki boyu (cm) bakımından çeşitler arasında önemli farklılıkların bulunmadığı izlenebilmektedir. Çizelge 4'ten bitki boyuna ilişkin, çeşitlere ait ortalama değerlerin, 251.8 ile $282.3 \mathrm{~cm}$ arasında değiştiği; KALIPSO çeşidinin en yüksek bitki boyu değerini (282.3) oluşturduğu, DKC6724 çeşidinin ise en düşük bitki boyu değerini (251.8) oluşturduğu saptanmıştır. Mısır çeşitlerinin bitki boyu ortalaması $268.5 \mathrm{~cm}$ olarak bulunmuştur. Bulgularımız; bitki boyu bakımından, Sarikurt (2005), Vartanlı (2005), Sezar ve ark. (2007), Öktem ve Öktem (2009), Atakul ve ark. (2014), Erdal (2014), Kahraman ve ark. (2014), Kılınç ve ark. (2014), Özata ve Kapar (2014), Kahraman (2016)'nın bulgulariyla benzerlik gösterirken; Cesurer (1994), Turgut ve ark. (2003), Babaoğlu (2003), Koca (2009), Özsisli (2010)'nin bulgularından daha yüksek değerler göstermiştir.

İlk Koçan Yüksekliği (cm): Çizelge 4 incelendiğinde ilk koçan yüksekliği $(\mathrm{cm})$ bakımından çeşitler arasında önemli farklılıkların bulunmadığı izlenebilmektedir. Tablo 4'ten ilk koçan yüksekliğine ilişkin, çeşitlere ait ortalama değerlerin, 88.0 ile $104.7 \mathrm{~cm}$ arasında değiştiği; SUERTO çeşidinin en yüksek ilk koçan yüksekliği değerini $(104.7 \mathrm{~cm})$ oluştururken, P1921 çeşidinin en düşük ilk koçan yüksekliği değerini (88.0 $\mathrm{cm}$ ) oluşturduğu saptanmıştır. Mısır çeşitlerinin ilk koçan yüksekliği ortalaması $98.3 \mathrm{~cm}$ olarak bulunmuştur. Bulgularımız; ilk koçan yüksekliği bakımından, Sarikurt (2005), Sezar ve ark. (2007), Öktem ve Öktem (2009), Koca (2009), Özsisli (2010), Atakul ve ark. (2014), Erdal (2014), Kahraman ve ark. (2014), Kılınç ve ark. (2014), Özata ve Kapar (2014), Kahraman (2016)'nın bulguları ile benzerlik gösterirken; Cesurer (1994), Turgut ve ark. (2003)'nın bulgularından daha yüksek değerler göstermiştir.

Sap Kalınlığı ( $\mathrm{mm})$ : Çizelge 4 incelendiğinde sap kalınlığı $(\mathrm{mm})$ bakımından çeşitler arasında \% 5 düzeyinde önemli farklllıkların bulunduğu izlenebilmektedir. Çizelge 4'ten, sap kalınlığ özelliğine ilişkin, çeşitlere ait ortalama değerlerin, 20.5 ile $23.5 \mathrm{~mm}$ arasında değiştiği; KALİPSO çeşidinin en yüksek sap kalınlığı değerine (23.5 mm) sahip grubu oluşturduğu, P1921 çeşidinin ise en düşük sap kalınlığ 1 değerine $(20.5 \mathrm{~mm})$ sahip grubu oluşturduğu saptanmıştır. Misır çeşitlerinin sap kalınlığı ortalaması $21.9 \mathrm{~mm}$ olarak bulunmuştur. KALIPSO çeşidi ile 70MAY82 çeşitleri sap kalınlığında yüksek değerler göstererek aynı istatistiki grupta yer almışlardır. Sap kalınlığı yönünden elde edilen bulgular, İdikut ve Kara (2013)'nın sap kalınlığının 21 - $24 \mathrm{~mm}$ arasında, Kahraman (2016)'nın sap kalınlığının18.9 - 23.7 mm arasında değiştiğini bildiren bulguları ile uyum gösterirken, Özsisli (2010)'nin sap kalınlığının 14.12 $16.37 \mathrm{~mm}$ arasında değiştiğini bildirdiği bulgularından daha yüksek, Sarikurt (2005)'in sap kalınlığının 33.4 - $36.8 \mathrm{~mm}$ arasında değiştiğini bildirdiği bulgularından daha düşük değerler göstermiştir.

Koçan Uzunluğu (cm): Çizelge 4 incelendiğinde koçan uzunluğu (cm) bakımından çeşitler arasında \% 1 düzeyinde önemli farklılıkların bulunduğu izlenebilmektedir. Çizelge 4'ten, koçan uzunluğu özelliğine ilişkin, çeşitlere ait ortalama değerlerin, 19.5 ile $22.0 \mathrm{~cm}$ arasında değiştiği; 70MAY82 çeşidinin en yüksek koçan uzunluğu değerine $(22.0 \mathrm{~cm})$ sahip grubu oluşturduğu, DKC6724 çeşidinin ise en düşük koçan uzunluğu değerine $(19.5 \mathrm{~cm})$ sahip grubu oluşturduğu saptanmıştır. Mısır çeşitlerinin koçan uzunluğu ortalaması $20.8 \mathrm{~cm}$ olarak bulunmuştur. 70MAY82, KALIPSO çeşidi ile P1921 çeşitleri koçan uzunluğunda yüksek değerler göstererek aynı istatistiki grupta yer almışlardır. Genelde yüksek verimli çeşitlerin koçan uzunlukları ve çaplarının da

yüksek olduğu gözlenmiştir. (Tekkanat ve Soylu, 2005). Koçan uzunluğunun çevre şartlarından etkilendiğini belirten birçok çalışma vardır. Genotip ve çevre interaksyonunun koçan uzunluğu üzerine önemli etkisi bulunmaktadır (Özmen, 2008). Bulgularımız; Turgut ve ark. (2003), Babaoğlu (2003), Vartanlı (2005), Sezar ve ark. (2007), Koca (2009), İdikut ve Kara (2013), Kahraman (2016)'nın bulgularıla paralellik gösterirken, Sarikurt (2005)'un bulgularından daha yüksek değerler elde edilmiştir.

Koçan Kalınlığı (mm): Çizelge 4 incelendiğinde koçan kalınlığı $(\mathrm{mm})$ bakımından çeşitler arasında \% 1 düzeyinde önemli farklılıkların bulunduğu izlenebilmektedir. Çizelge 4'ten, koçan kalınlığı özelliğine ilişkin, çeşitlere ait ortalama değerlerin, 44.5 ile $49.0 \mathrm{~mm}$ arasında değiştiği; DKC6724 çeşidinin en yüksek koçan kalınlığı değerine $(49.0 \mathrm{~mm})$ sahip grubu oluşturduğu, 70MAY82 çeşidinin ise en düşük koçan kalınlığı değerine (44.5 mm) sahip grubu oluşturduğu saptanmıştır. Mısır çeşitlerinin koçan kalınlığı ortalaması $46.5 \mathrm{~mm}$ olarak bulunmuştur. Mısırda koçan kalınlığ doğrudan verimi etkileyen önemli bir özelliktir. Koçan kalınlığı arttıkça koçan sıra sayısı artmaktadır. Koçan kalınlığının çevre 
şartlarından etkilendiğini belirten birçok çalışma vardır. Genotip ve çevre interaksyonunun koçan kalınlığı üzerine etkisi önemlidir (Özmen, 2008). Bulgularımız; Babaoğlu (2003), Sarikurt (2005), Sezer ve ark. (2007), Kahraman (2016)'nın bulgulariyla paralellik gösterirken, Vartanlı (2005)'nın bulgularından daha düşük, Özsisli (2010)'nin bulgularından daha yüksek değerler elde edilmiştir.

Bitkide koçan sayısı, tane/koçan oranı, 1000 tane ağırlığı, tane nemi ve tane verimi ortalama değerleri ile $\operatorname{LSD}_{(0.05)}$ testine göre oluşan gruplar Çizelge 5 'te verilmiştir.

Çizelge 5. Bitkide koçan sayısı, tane/koçan oranı, 1000 tane ağırlığı, tane nemi, tane verimi ortalama değerleri.

\begin{tabular}{llllll}
\hline Çeşit & $\begin{array}{l}\text { Bitkide } \\
\left.\text { Sayısı(adet bitki }{ }^{-1}\right)\end{array}$ & $\begin{array}{l}\text { Tane /Koçan } \\
\text { Oranı }(\%)\end{array}$ & $\begin{array}{l}1000 \\
\text { Ağırlığ }(\mathrm{g})\end{array}$ & $\begin{array}{l}\text { Tane } \\
\text { Tane Nemi(\%) }\end{array}$ & $\begin{array}{l}\text { Tane Verimi } \\
\left(\mathrm{kg} \mathrm{da}^{-1}\right)\end{array}$ \\
\hline PR31D24 & $1.04 \mathrm{a}$ & $87.5 \mathrm{ab}$ & $350.8 \mathrm{c}$ & $11.55 \mathrm{~d}$ & 1375.16 \\
SUERTO & $0.97 \mathrm{~b}$ & $85.7 \mathrm{~b}$ & $294.2 \mathrm{e}$ & $13.95 \mathrm{~b}$ & 1232.61 \\
70MAY82 & $0.99 \mathrm{~b}$ & $85.6 \mathrm{~b}$ & $387.5 \mathrm{a}$ & $16.43 \mathrm{a}$ & 1348.81 \\
KALIPSO & $0.99 \mathrm{~b}$ & $87.4 \mathrm{ab}$ & $370.8 \mathrm{~b}$ & $9.53 \mathrm{e}$ & 1445.11 \\
P1921 & $1.00 \mathrm{ab}$ & $88.5 \mathrm{a}$ & $337.3 \mathrm{~cd}$ & $10.58 \mathrm{~d}$ & 1518.10 \\
DKC6724 & $1.04 \mathrm{a}$ & $87.4 \mathrm{ab}$ & $333.8 \mathrm{~d}$ & $12.63 \mathrm{c}$ & 1462.19 \\
\hline ORTALAMALAR & 1.00 & 87.0 & 345.7 & 12.44 & 1396.99 \\
\hline LSD $(0,05)$ & $0.04^{*}$ & $2.03^{*}$ & $16.43^{* *}$ & $1.01^{* *}$ & Ö.D \\
\hline CV(\%) & 3.01 & 1.55 & 3.15 & 5.39 & 12.34 \\
\hline
\end{tabular}

* Aynı harfle gösterilen ortalamalar arasındaki farklar 0.05 düzeyinde önemli değildir.

**Aynı harfle gösterilen ortalamalar arasındaki farklar 0,01 düzeyinde önemli değildir

Çizelge 5 incelendiğinde, çeşitler arasında bitkide koçan sayısı ve tane koçan oranı bakımından \% 5 düzeyinde, 1000 tane ağırlığı ve tane nemi bakımından \% 1 düzeyinde önemli bir farklılığın olduğu, tane veriminde ise farklılığın önemli olmadığı tespit edilmiştir.

Bitkide Koçan Sayısı (adet bitki ${ }^{-1)}$ : Çizelge 5 incelendiğinde bitkide koçan sayısı (adet/bitki) bakımından çeşitler arasında \%5 düzeyinde önemli farklılıkların bulunduğu izlenebilmektedir. Çizelge 5 'ten, bitkide koçan sayısı özelliğine ilişkin, çeşitlere ait ortalama değerlerin, 0.97 ile 1.04 adet/bitki arasında değiştiği; PR31D24 ile DKC6724 çeşitlerinin en yüksek bitki koçan sayısı değerine (1.04 adet/bitki) sahip grubu oluştururken, SUERTO çeşidinin ise en düşük bitki koçan sayısı değerine (0.97) sahip grubu oluşturduğu saptanmıştır. Mısır çeşitlerinin bitki koçan sayısı ortalaması 1.00 adet/bitki olarak bulunmuştur. PR31D24 çeşidi ile DKC6724 çeşitleri bitkide koçan sayısı bakımından yüksek değerler göstererek aynı istatistiki grupta yer almışlardır. Çok koçanlılık istenen bir özellik değildir. Birçok araştırıcı çok koçanlılığın verimde düşüşlere sebep olduğunu söylemektedir. Bulgularımız; Babaoğlu (2003), Sarikurt (2005), Kahraman (2016)'nın bulgulariyla paralellik göstermektedir.

Tane /Koçan Oranı (\%): Çizelge 5 incelendiğinde tane/koçan oranı (\%) bakımından çeşitler arasında \% 5 düzeyinde önemli farklılıkların bulunduğu izlenebilmektedir. Çizelge 5'ten, tane/koçan oranı özelliğine ilişkin, çeşitlere ait ortalama değerlerin \% 85.6 ile 88.5 arasında değiştiği; P1921 çeşidinin en yüksek tane/koçan oranı değerine (\% 88.5) sahip grubu oluştururken, 70MAY82 çeşidinin en düşük tane/koçan oranı değerine (\% 85.6) sahip grubu oluşturduğu saptanmıştır. Mısır çeşitlerinin tane/koçan oranı ortalaması \% 87.0 olarak bulunmuştur. P1921, KALIPSO ile DKC6724 çeşitleri bitkide tane/koçan oranında yüksek değerler göstererek aynı istatistiki grupta yer almışlardır. Bulgularımız; Atakul ve ark. (2014), Erdal (2014), Kahraman ve ark. (2014), Kılınç ve ark. (2014), Kahraman (2016)'nın bulgularıyla benzerlik gösterirken, Sezer ve ark. (2007)'nın bulgularından daha düşük değerler göstermiştir. Bu farkın denemeye alınan çeşitler arasındaki genetik yapı farklılıklarından ve her çeşidin belirli bir çevreye olan farklı tepkilerinden kaynaklandığı düşünülmektedir.

1000 Tane Ağırlığı (g): Çizelge 5 incelendiğinde 1000 tane ağırlığı (g) bakımından çeşitler arasında \% 1 düzeyinde önemli farklıllkların bulunduğu izlenebilmektedir Çizelge 5’ten, 1000 tane ağırlığı özelliğine ilişkin, çeşitlere ait ortalama değerlerin, 294.2 ile 387.5 g arasında değiş̧tiği; 70MAY82 çeşidinin en yüksek 1000 tane ağırlığı değerine (387.5 g) sahip olduğu, SUERTO çeşidinin ise en düşük 1000 tane ağırlığ 1 değerine $(294.2$ g) sahip olduğu saptanmıştır. Mısır çeşitlerinin 1000 tane ağırlı̆̆ ortalaması $345.7 \mathrm{~g}$ olarak bulunmuştur. Bulgularımız; Turgut ve ark. (2003) Babaoğlu (2003), Özsisli (2010), Atakul ve ark. (2014), Erdal (2014), Kahraman ve ark. (2014), Kılınç ve ark. (2014), Kahraman (2016)'nın bulgularıyla benzerlik gösterirken, Traore ve ark. (2000), Elmalı ve Soylu (2008)'nun bulgularından yüksek, Sezer ve ark. (2007)'nın bulgularından daha düşük değerler göstermiştir. 
Tane Nemi (\%): Çizelge 5 incelendiğinde tane nemi (\%) bakımından çeşitler arasında \% 1 düzeyinde önemli farklılıkların bulunduğu izlenebilmektedir. Çizelge 5'ten tane nemi özelliğine ilişkin, çeşitlere ait ortalama değerlerin \% 9.53 ile 16.43 arasinda değiştiği; 70MAY82 çeşidinin en yüksek tane nemi değerine (\% 16.43) sahip grubu oluşturduğu, KALIPSO çeşidinin ise en düşük tane nemi değerine (\% 9.53) sahip grubu oluşturduğu saptanmıştır. Mısır çeşitlerinin tane nemi ortalaması \% 12.44 olarak bulunmuştur. Bulgularımız; Özsisli (2010), Atakul ve ark.(2014), Kılınç ve ark. (2014), Erdal (2014), Kahraman (2016)'nın bulgulariyla benzerlik gösterirken, Vartanlı (2005), Öktem ve Öktem (2009) Özata ve Kapar (2014)'ın bulgularından daha düşük değerler göstermiştir. Özmen (2008) hasatta tane nemi yönünden genotip x çevre interaksiyonunun önemli olduğunu bildirmiştir.

Tane Verimi (kg da ${ }^{-1)}$ : Çizelge 5'ten tane verimi (kg/da) bakımından çeşitler arasında önemli farklılıkların bulunmadığı izlenebilmektedir. Çizelge 5'ten tane verimine ilişkin, çeşitlere ait ortalama değerlerin, 1232.61 ile $1518.10 \mathrm{~kg} / \mathrm{da}$ arasında değiştiği, P1921 çeşidinin en yüksek tane verimi değerini (1518.10 $\mathrm{kg} / \mathrm{da}$ ) oluşturduğu, SUERTO çeşidinin ise en düşük tane verimi değerini $(1232.61 \mathrm{~kg} / \mathrm{da})$ oluşturduğu saptanmıştır. Mısır çeşitlerinin tane verimi ortalamasının $1396.99 \mathrm{~kg} / \mathrm{da}$ olduğu belirlenmiştir. P1921, KALIPSO ile DKC6724 çeşitlerinin verimlerinin yüksek olduğu görülmektedir.

Bulgularımız; Howell ve ark. (1996), Sarikurt (2005), Atakul ve ark. (2014), Kılınç ve ark. (2014), Kahraman (2016)'nın bulguları ile benzerlik gösterirken, Cesurer (1994), Mankong (2000), Babaoğlu (2003), Turgut ve ark. (2003), Sezer ve ark. (2007), Elmalı ve Soylu (2008), Koca (2009), Özsisli (2010), İdikut ve Kara (2013), Özata ve Kapar (2014)'ın bulgularından daha yüksek, Vartanlı (2005)'nın bulgularından daha düşük değerler göstermiş̧ir.

Ham protein oranı, nişasta oranı, ham yağ oranı ile hektolitre ağırlığına ait ortalama değerler ve $\operatorname{LSD}_{(0.05)}$ testine göre oluşan gruplar Çizelge 6’da verilmiştir.

Çizelge 6. Ham protein oranı, nişasta oranı, ham yağ oranı, hektolitre ağırlığı ortalama değerleri.

\begin{tabular}{|c|c|c|c|c|c|}
\hline Çeşit & $\begin{array}{l}\text { Ham } \\
\text { Oranı(\%) }\end{array}$ & Protein & Nişasta Oranı (\%) & Ham Yağ Oranı(\%) & $\begin{array}{l}\text { Hektolitre } \\
\text { ağgrlığ } 1\left(\mathrm{~kg} \mathrm{hl}^{-1}\right)\end{array}$ \\
\hline PR31D24 & 8.6 & & $65.20 \mathrm{ab}$ & $3.33 \mathrm{c}$ & $83.68 \mathrm{a}$ \\
\hline SUERTO & 7.9 & & $65.03 \mathrm{bc}$ & $4.00 \mathrm{a}$ & $82.45 \mathrm{~b}$ \\
\hline 70MAY82 & 9.0 & & $65.57 \mathrm{a}$ & $3.58 \mathrm{~b}$ & $81.48 \mathrm{c}$ \\
\hline KALIPSO & 7.8 & & $64.69 \mathrm{c}$ & $3.50 \mathrm{bc}$ & $79.35 \mathrm{~d}$ \\
\hline P1921 & 8.0 & & $65.29 \mathrm{ab}$ & $3.53 \mathrm{~b}$ & $84.00 \mathrm{a}$ \\
\hline DKC6724 & 7.8 & & $64.28 \mathrm{~d}$ & $3.40 \mathrm{bc}$ & $79.10 \mathrm{~d}$ \\
\hline ORTALAMALAR & 8.2 & & 65.01 & 3.54 & 81.67 \\
\hline $\operatorname{LSD}_{(0, .05)}$ & Ö.D & & $0.40^{* *}$ & $0.19^{* *}$ & $0.61^{* *}$ \\
\hline CV(\%) & 7.10 & & 0.41 & 3.61 & 0.49 \\
\hline
\end{tabular}

* Aynı harfle gösterilen ortalamalar arasındaki farklar 0.05 düzeyinde önemli değildir

**Aynı harfle gösterilen ortalamalar arasındaki farklar 0,01 düzeyinde önemli değildir

Çizelge 6 incelendiğinde, çeşitler arasında ham protein oranı bakımından önemli bir fark bulunmamakla birlikte nişasta oranı, ham yağ oranı ve hektolitre ağırlığı bakımından çeşitler arasında \% 1 önem düzeyinde istatistiksel farklılıkların olduğu tespit edilmiştir.

Ham Protein Oranı(\%): Çizelge 6 incelendiğinde ham protein oranı (\%) bakımından çeşitler arasında önemli farklılıkların bulunmadığ izlenebilmektedir. Çizelge 6'dan ham protein oranına ilişkin, çeşitlere ait ortalama değerlerin, \%7.8 ile \% 9.0 arasında değiştiği; 70MAY82 çeşidinin en yüksek ham protein oranı değerini (\% 9.0) oluştururken, DKC6724 ile KALIPSO çeşitlerinin en düşük ham protein oranı değerini (\% 7.8) oluşturduğu saptanmıştır. Mısır çeşitlerinin ham protein oranı ortalaması \% 8.2 olarak bulunmuştur. Bulgularımız; Uyar (1989), Vartanlı (2005), Elmalı ve Soylu (2008), Koca (2009), Özsisli (2010), Kahraman (2016)'nın bulgularıyla benzerlik gösterirken, Dudley ve ark. (2004), Tekkanat ve Soylu (2008), Koca (2009),
Cengiz ve ark. (2014), Özata ve Kapar (2014)'ın bulgularından daha düşük değerler göstermiştir.

Nişasta Oranı (\%): Çizelge 6 incelendiğinde nişasta oranı (\%) bakımından çeşitler arasında \% 1 düzeyinde önemli farklılıkların bulunduğu izlenebilmektedir. Çizelge 6'dan, nişasta oranı özelliğine ilişkin, çeşitlere ait ortalama değerlerin, \% 64.28 ile \% 65.57 arasında değiştiği; 70MAY82 çeşidinin en yüksek nişasta oranı değerine (\% 65.57) sahip grubu oluşturduğu, DKC6724 çeşidinin ise en düşük nişasta oranı değerine (\% 64.28) sahip grubu oluşturduğu saptanmıştır. Mısır çeşitlerinin nişasta oranı ortalaması \% 65.01 olarak bulunmuştur. 70MAY82, P1921 ve PR31D24 çeşitleri nişasta oranı bakımından yüksek değerler göstermiştir. Bulgularımız; Özsisli (2010) ile Özata ve Kapar (2014)'in bulgularından yüksek, Kahraman (2016)'nın bulgularından düşük değerler göstermiştir.

Ham Yağ Oranı(\%): Çizelge 6'dan ham yağ oranı (\%) bakımından çeşitler arasında \% 1 düzeyinde önemli 
farklılıkların bulunduğu izlenebilmektedir. Çizelge 6'dan, ham yağ oranı özelliğine ilişkin, çeşitlere ait ortalama değerlerin, \% 3.33 ile \% 4.00 arasinda değiştiği; SUERTO çeşidinin en yüksek ham yağ oranı değerine (\% 4.00) sahip grubu oluşturduğu, PR31D24 çeşidinin ise en düşük ham yağ oranı değerine (\% 3.33) sahip grubu oluşturduğu saptanmıştır. Mısır çeşitlerinin ham yağ oranı ortalaması \% 3.54 olarak bulunmuştur. Bulgularımız; Babaoğlu (2003), Vartanlı (2005), Koca (2009), Özsisli (2010), Özata ve Kapar (2014), Kahraman (2016)'nın bulguları ile paralellik gösterirken, Uyar (1989), Dudley ve ark. (2004) Cengiz ve ark. (2014)'nın bulgularından daha düşük değerler elde edilmiştir.

Hektolitre Ağırlığı(kg hl-1): Çizelge 6'dan hektolitre ağırlığı $(\mathrm{kg} / \mathrm{hl})$ bakımından çeşitler arasında \% 1 düzeyinde önemli farklılıkların bulunduğu izlenebilmektedir. Çizelge 6'dan, hektolitre ağırlığ özelliğine ilişkin, çeşitlere ait ortalama değerlerin, 79.10 ile $84.00 \mathrm{~kg} / \mathrm{hl}$ arasında değiştiği; P1921 çeşidinin en yüksek hektolitre ağırlığı değerine (84.00 $\mathrm{kg} / \mathrm{hl}$ ) sahip olduğu, DKC6724 çeşidinin ise en düşük hektolitre ağırlığı değerine $(79.10 \mathrm{~kg} / \mathrm{hl})$ sahip olduğu saptanmıştır. Mısır çeşitlerinin hektolitre ağırlığı ortalaması $81.67 \mathrm{~kg} / \mathrm{hl}$ olarak bulunmuştur. P1921 ve PR31D24 çeşitleri hektolitre ağırlığ bakımından yüksek değer göstererek aynı gurupta yer almıştır. Bulgularımız; Babaoğlu (2003), Tekkanat ve Soylu (2005), Vartanlı (2005), Koca (2009), Özsisli (2010)'un bulguları ile paralellik gösterirken, Elmalı ve Soylu (2008)'nun bulgularından daha yüksek değerler elde edilmiştir. Özmen (2008) hektolitre ağırlığında genotip xçevre interaksiyonunun önemli olduğunu bildirmiş̧tir.

\section{SONUÇ}

Diyarbakır koşullarında yapılan çalışmada elde edilen sonuçlar doğrultusunda çeşitlerin incelenen özellikler, verim ve verim unsurları göz önüne alındığında mevcut çeşitler içerisinde; P1921, DKC6724 ve KALIPSO çeşitleri öne çıkmıştır. En yüksek verim P1921 çeşidinden elde edilmiştir.

\section{TEŞEKKÜR}

"Bu çalışma Siirt Üniversitesi Bilimsel Araştırma Projeleri (SIÜBAP) Koordinatörlüğü tarafından desteklenmiştir. Proje Kodu: 2015-Sİ̈̈FEB-40"

Araştırma yüksek lisans çalışmasından türetilmiştir.

\section{KAYNAKLAR}

Anonim 2011. Diyarbakır İ Çevre Durum Raporu. http/www.csb.gov.tr (Erişim Tarihi: 27.10.2015).

Anonim 2015. Coğrafya Dünyası, İl İl Türkiye, İklim ve Bitki Örtüsü http://www.cografya.gen.tr/tr/ diyarbakir/iklim.html(Erişim Tarihi: 27.10.2015).

Anonim 2016a. Food and Agriculture Organization. www.faostat.org.( Erişim tarihi: 08.02.2016)
Anonim 2016b. Bitkisel üretim verileri İstatistikleri. Türkiye İstatistik Kurumu. www.tuik.gov.tr( Erişim tarihi: 08.02.2016).

Atakul Ş, Kahraman Ș, Kılınç S 2014. Diyarbakır ana ürün şartlarında bazı tane mısır genotiplerinin verim ve verim unsurlarının belirlenmesi. Uluslararası Mezopotamya Tarım Kongresi 22-25 Eylül, Diyarbakır

Babaoğlu M 2003. Farklı Kökenli Mısır (Zea mays L. ) Genotiplerinin Çeşitli Agronomik Ve Kalite Karakterleri Bakımından Karşılaştırmalı Olarak Değerlendirilmesi. Trakya Üniversitesi Fen Bilimleri Enstitüsü, Tarla Bitkileri ABD Yüksek Lisans Tezi. $108 \mathrm{~s}$.

Cengiz R, Cengiz B, Esmeray M, Sezer MC, Akarken N, Özbey AE, Duman A 2014. Tanede Protein ve Yağ Kalite Değerlerine Göre Sentetik Mısır Kaynak Materyalleri Geliştirme. Uluslararası Mezopotamya Tarım Kongresi 22-25 Eylül, Diyarbakır

Cesurer L 1994. Kahramanmaraş Koşullarında Ana Ürün Olarak Yetiştirilebilecek Yüksek Verimli Melez Mısır Çesitleri Üzerinde Araştırmalar. Türkiye 1.Tarla Bitkileri Kongresi, 25-29 Nisan, Cilt: 1, S:267 - 270, IZMIR.

Dudley, J.W., Dijkhuizen, A., Paul, C., Coates, S.T., Rocheford, T.R., 2004. Effects of random mating on marker-QTL associations in the cross of the illinois high protein $\mathrm{x}$ illinois low protein maize strains. Crop Sci. 44: 1419-1428.

Elmalı H, Soylu S 2008. Melez Atdişi Mısırda Farklı Taban Gübresi Çeşitlerinin Tane Verimi, Verim Unsurları Ve Kalite Üzerine Etkileri. S.Ü. Ziraat Fakültesi Dergisi 22 (44): 104-112.

Erdal Ş 2014. Kendilenmiş Mısır (Zea mays L.) Hatlarının Kuraklık Stresine Tolerans Düzeylerinin Belirlenmesi ve Moleküler Karakterizasyonu. Süleyman Demirel Üniversitesi Fen Bilimleri Enstitüsü, Tarla Bitkileri Anabilim Dalı , Doktora Tezi, $207 \mathrm{~s}$.

Howell TA, Evett SR, Tolk JA, Schneider AD and Steiner JL 1996. Evapotranspiration of Corn Southern High Plains. American society of Agricultural Engineers, $158-166$.

İdikut L ve Kara SN 2013. Tane Ürünü İçin Yetiştirilen İkinci Ürün Mısır Çeşitlerinin Bazı Verim Öğeleri İle Tane Nişasta Oranlarının Belirlenmesi. KSÜ Doğa Bil. Dergisi, 16(1), : 8- 15.

Kahraman Ş, Kılınç S, Atakul Ş 2014. Tek Melez Mısır Genotiplerinin Diyarbakır Şartlarındaki Performanslarının Belirlenmesi. Uluslararası Mezopotamya Tarım Kongresi 22-25 Eylül, Diyarbakır

Kahraman Ş. 2016. Diyarbakır Koşullarında Ana Ve İkinci Ürün Tane Mısır Tarımında Bazı Tarımsal ve Teknolojik Özellikler Üzerine Araştırmalar. Dicle Üniversitesi Fen Bilimleri Enstitüsü, Tarla Bitkileri ABD, Doktora Tezi,167 s. 
Kılınç S, Atakul Ş, Kahraman Ş 2014. Bazı Melez Mısır Genotiplerinin Adaptasyon ve Uyum Yeteneklerinin Belirlenmesi. Uluslararası Mezopotamya Tarım Kongresi 22-25 Eylül, Diyarbakır

Koca YO 2009. Aydın Bölgesinde, Birinci ve İkinci Ürün Mısırda (Zea mays L.) Verim, Verim Öğeleri, Fizyolojik ve Diğer Bazı Özellikler Arasındaki Farklllıklar. Adnan Menderes Üniversitesi Fen Bilimleri Enstitüsü, Tarla Bitkileri ABD , Doktora Tezi, $122 \mathrm{~s}$.

Mankong M C 2000. Estimation of Genetic Coefficients of Thai Hybrid Varieties for the CERES - Maize Model. www.grad.cmu.oc.th/abstract

Öktem A Öktem AG 2009. Bazı Atdişi Hibrit Mısır (Zea mays L. indentata) Genotiplerinin Harran Ovası Koşullarında Performanslarının Belirlenmesi. Harran Üniversitesi Ziraat Fakültesi Dergisi,13(2):49-58

Özata E ve Kapar H 2014. Bazı Atdişi Hibrit Mısır (Zea mays indentata Sturt) Genotiplerinin Samsun Koşullarında Kalite Ve Performanslarının Belirlenmesi. Tarım Bilimleri Araştırma Dergisi 7 (2): 01-07,

Özmen İ 2008. Bazı Melez Mısır Çeşit Ve Genotiplerinin Değişik Ekim Bölgelerindeki Adaptasyon ve Uyum Yeteneklerinin Belirlenmesi Üzerine Araştırmalar. Ege Üniversitesi Fen Bilimleri Enstitüsü Tarla Bitkileri ABD, Doktora Tezi. $128 \mathrm{~s}$.

Özsisli B 2010. Kahramanmaraş Koşullarında Birinci ve Ikinci Ürün Olarak Yetiştirilen Farklı Mısır Çeşitlerinde Verim ve Kalite Özelliklerinin Incelenmesi. Kahramanmaraş Sütçü İmam Üniversitesi Fen Bilimleri Enstitüsü, Tarla Bitkileri ABD, Doktora tezi, $130 \mathrm{~s}$.

Sarikurt B 2005. Diyarbakır Sulu Koşullarında II. Ürün Olarak Yetiştirilen Bazı Mısır Çeşitlerinde Verim ve Bazı Tarımsal Karakterler İle Karakterler Arası İlişkilerin Saptanması. Harran
Üniversitesi Fen Bilimleri Enstitüsü, Tarla Bitkileri ABD, Yüksek Lisans Tezi, $49 \mathrm{~s}$.

Sezer I, Mut Z, Öner F, Sirat A, Gülümser A 2007. Bafra Ovasında Ana Ürün Olarak Yetiştirilebilecek Mısır Çeşitlerinin (Zea mays L. İndendata) Belirlenmesi Üzerine Araştırma. Türkiye VII. Tarla Bitkileri Kongresi, 25-27 Haziran, Erzurum.

Tarımsal Değerleri Ölçme Denemeleri Teknik Talimatı, Tarım Gıda ve Hayvancılık Bakanlığı, 2010.

Tekkanat A, Soylu S, 2005. Cin Mısırı Çeşitlerinin Tane Verimi Ve Önemli Kalite Özelliklerinin Belirlenmesi. Selçuk Üniversitesi Ziraat Fakültesi Dergisi, 19 (37):51-60.

Traore SB, Carlson RE, Pilcher CD, Rice ME 2000. Bt and Non- Bt Maize Growth and Development as Affected by Temperature and Drought Stres. Agronomy Journal 92: 1027-1035.

Turgut İ, Duman A, Balcı A 2003. Kendilenmiş Mısır (Zea mays İndentata Sturt.) Hatlarının Yoklama Melezlerinde, Verim ve Verim Öğeleri Bakımından Heterosis ve Kombinasyon Yeteneği Değerlerinin Belirlenmesi Uludağ Üniversitesi Ziraat Fakültesi Dergisi, 17(2): 47-56

Uyar İ 1989. Bornova Kosullarında 13 Melez Misır Çesidinin ikinci Ürün Olarak Bazı Agronomik ve Kalite Özellikleri Üzerinde Çalısmalar. Ege Üniversitesi Fen Bilimleri Enstitüsü, Tarla Bitkileri ABD, Yüksek Lisans Tezi, $32 \mathrm{~s}$.

Vartanlı S 2005. Ankara Koşullarında Hibrit Mısır Çesitlerinin Verim ve Kalite Özelliklerinin Belirlenmesi. Ankara Üniversitesi Fen Bilimleri Enstitüsü, Tarla Bitkileri ABD, Yüksek Lisans Tezi. $80 \mathrm{~s}$.

Vartanlı S, Emeklier HY 2007. Ankara Koşullarında Hibrit Mısır Çeşitlerinin Verim Ve Kalite Özelliklerinin Belirlenmesi. Ankara Üniversitesi Ziraat Fakültesi Tarım Bilimleri Dergisi. 13 (3): 195-202. 